\title{
MUTAGEN EFFECT ON THE GROWTH, PHYSIOLOGY AND MICROSTRUCTURE OF ALFALFA (MEDICAGO SATIVA L)
}

\author{
SHEN, X. H. ${ }^{1,2 \dagger}-$ JIANG, C. ${ }^{2 \dagger}-$ ZHENG, W. $.^{1 \dagger}-$ FENG, P. ${ }^{1 \dagger}-$ WANG, Q. ${ }^{3}-$ LAI, Y. C..$^{1 *}$ \\ ${ }^{1}$ Postdoctoral Workstation of Heilongjiang Academy of Agricultural Sciences, Harbin 150086, \\ China
}

${ }^{2}$ College of Life Sciences, Resources and Environment Sciences, Yichun University, Yichun, Jiangxi 336000, China

${ }^{3}$ Breeding Unit of the Academy of Agricultural Sciences in Heilongjiang Province, Harbin, Heilongjiang 150000, China

${ }^{\top}$ These authors have contributed equally to this work

*Corresponding author

e-mail:nxysxh@163.com; phone/fax:+86-135-0360-5775

(Received 27 $7^{\text {th }}$ Nov 2019; accepted 24 ${ }^{\text {th }}$ Mar 2020)

\begin{abstract}
In order to study the effect of mutagenesis on growth, physiology and cell structure in alfalfa (Medicago sativa $\mathrm{L}$ ), the seeds of Longmu806 were treated with two kinds of mutagenesis methods including ${ }^{60} \mathrm{Co}-\gamma$ irradiation $(50,150,300,450,600 \mathrm{~Gy}$ ) and EMS (ethyl methane sulfonate $0.1 \%, 0.2 \%$, $0.4 \%(\mathrm{v} / \mathrm{v}))$. The results showed that the seed germination rate, seedling growth, fresh grass yield and plant height were significantly $(P<0.05)$ higher than their corresponding controls under 50-150 Gy, and then decreased with the increasing of radiation dose. However, these indicators decreased with the increasing of EMS concentration. Two mutagenic treatments increased alfalfa branch number. The chlorophyll content was promoted by a dose of 50-150 Gy and 0.4\% EMS concentration. It was also found that mutagenic treatments could promote the activity of three anti-oxidant enzymes including superoxide dismutase (SOD), peroxidase (POD) and hydrogen peroxidase (CAT), and the highest antioxidant enzyme activity was $150 \mathrm{~Gy}{ }^{60} \mathrm{Co}-\gamma$ irradiation and $0.4 \%$ EMS treatment. The leaf thicknesses increased, the vein protuberant degrees decreased and the compactness of cell structure was enhanced. Being more conducive for screening mutants, ${ }^{60} \mathrm{Co}-\gamma$ irradiation with 150 Gy and EMS with $0.4 \%$ were the ideal mutagenic treatments.
\end{abstract}

Keywords: ${ }^{60} \mathrm{Co}-\gamma$ irradiation, ethyl methane sulfonate, seedling growth, antioxidant enzyme activity, chlorophyll content

\section{Introduction}

Alfalfa (Medicago sativa L.) is very important legume forage crop, which has been planted all over the world. However, in alpine areas such as northeast China, short frostfree period, narrow genetic basis, low harvest index and widespread biotic and abiotic stresses constrains alfalfa production, and feed supplies are often insufficient in some years, which seriously restricts the production productivity of livestock (Shen et al., 2016; Nan et al., 2011). Modern biotechnological approaches, including mutagenic technology, are gaining interest to augment the efforts of alfalfa genetic improvement (Jain, 2011).

The mutagen is very efficient for creating genetic variability in the natural gene pool of crops (Kumari et al., 2016; Kumar et al., 2010). It provides raw materials for the genetic improvement of any crop (Adamu et al., 2004). Artificial mutagenesis can be used to induce mutations in crop plants and subsequent improvement be done through 
selection. They made a significant contribution to agricultural development. Some scholars have screened a number of new varieties through mutagenic research on alfalfa. For example, Zhang et al. (2007) have selected a new alfalfa variety Nongjing 1 from Longmu 803 mutant through magnetic field free space; and selected alfalfa varieties Nongjing 8 and Nongjing 10 from Zhaodong alfalfa and Longmu 803 mutant by satellite.

Some reports provide evidence of a stimulating effect on growth and physiological characteristics when seeds or seedlings are treated at different mutation (Zhang et al., 2017). The growth and physiological responses of alfalfa to mutagens were elucidated (Dhawi and Al-Khayri, 2011). Mutagenesis inflicted modifications in seedling growth (Li et al., 2013); chlorophyll (Dhawi and Al-Khayri, 2008); SOD, POD, CAT and MDA (Dhawi and Al-Khayri, 2008); and water content as well as growth expressed in fresh weight (Dhawi and Khayri, 2009). Wu et al. (2015) discovered that the EMS mutagenesis treatment can inhibit the germination and growth of alfalfa seeds. In higher plants, the structure of the cell changes under different degrees of environmental and mutagenic stresses and is closely related to the degree of stresses implied and the inherent stress resistance capacity of the plant. Zhang et al. (2010) reported that after the space mutagenesis, the leaf thicknesses of alfalfa increased and the palisade tissues were significantly thickened. The mutants provide materials to be selected for breeding. The above studies have shown that mutagenesis can change the physiological and growth characteristics of alfalfa, and has practical production significance for alfalfa breeding research.

In this study, we selected ${ }^{60} \mathrm{Co}-\gamma$ radiation and EMS two types of mutagenesis treatments, because they had higher mutagenic efficiency, their mutant materials were more abundant, and can lead to be helpful to improve cold resistance of alfalfa. The two mutagenesis methods operations were simple and low in cost. The study aim to comprehensive understand the effects of physical mutagenesis and chemical mutagenesis on alfalfa growth, physiological characteristics and cell structure, and provide a theoretical basis for the selection of resistant mutant in the alpine region and the selection of new forage varieties.

\section{Materials and methods}

\section{Climatic condition}

An experimental field was established in the Jiamusi City, which was located in the east part of the Heilongjiang Province, P. R. of China, 2017. The longitude is $129^{\circ} 30^{\prime}-$ $135^{\circ} 5^{\prime} \mathrm{E}$, and its latitude $45^{\circ} 56^{\prime}-48^{\circ} 27^{\prime} \mathrm{N}$. This region has a climate type of cold humid monsoon with annual average temperature of $3{ }^{\circ} \mathrm{C}$, annual average precipitation of $489.8 \mathrm{~mm}$, annual sunshine of $2052.3 \mathrm{~h}$, annual active accumulative temperature of $2500{ }^{\circ} \mathrm{C}$, and the annual average frost-free period is $128.9 \mathrm{~d}$.

\section{Growth condition}

The row to row and plant to plant spacing were kept at $30 \mathrm{~cm}$ and $12 \mathrm{~cm}$, respectively. The organic matter was $2.49 \%$ in the tested meadow black soil with available nitrogen $86.3 \mathrm{mg} \cdot \mathrm{kg}^{-1}$, available phosphorus $64.6 \mathrm{mg} \cdot \mathrm{kg}^{-1}$, available potassium $79.9 \mathrm{mg} \cdot \mathrm{kg}^{-1}$. Its total nitrogen, phosphorus, potassium was $0.14 \%, 0.15 \%$, and $3.12 \%$, respectively. Its soil $\mathrm{pH}$ was 6.5 . The previous crop for this site was corn. 


\section{Plant materials}

The tested alfalfa (Medicago sativa L.) was local and widely cultivated variety Longmu806 (Shen et al., 2015). It was supplied by the Jiamusi branch of the Heilongjiang Academy of Agricultural Sciences.

\section{Experimental design}

${ }^{60}$ Co-ray irradiation

For ${ }^{60} \mathrm{Co}-\gamma$ irradiation treatment, the seeds taken from the aforementioned alfalfa were treated with $6{ }^{60} \mathrm{Co} \gamma$-ray irradiation doses viz., $50 \mathrm{~Gy}, 150 \mathrm{~Gy}, 300 \mathrm{~Gy}, 450 \mathrm{~Gy}$, 600 Gy (300 seeds per dose) from 60 cobalt source at the Institute of Atomic Energy Utilization of Chinese Academy of Agricultural Sciences. The dose of 0 was set as control. Each treatment lasted for 7 days.

\section{Ethyl methyl sulfonate (EMS)}

900 seeds taken from the aforementioned alfalfa were soaked with concentrated sulfuric acid for $5 \mathrm{~min}$, and then rinsed with distilled water several times. The treated seeds were completely water-swelled by soaking in the phosphate buffer $\left(100 \mathrm{mmol} \mathrm{L}^{-1}\right.$, $\mathrm{pH} 7.0)$ at $4{ }^{\circ} \mathrm{C}$ for $12 \mathrm{~h}$. The seeds thus treated with phosphate buffer, were subjected to $0.1,0.2$ and $0.4 \%(\mathrm{v} / \mathrm{v})$ EMS and incubated in the dark at room temperature for $15 \mathrm{~h}$. During the procedure, the seeds were gently shaken. Finally, the seeds were rinsed with distilled water repeatedly for removing the residual EMS from the seed surface (Feng et al., 2018).

\section{Germination percentage and seedling growth}

After mutagenic treatments, the seeds along with its control seeds were germinated on moist filter paper at $28{ }^{\circ} \mathrm{C}$. After 2 weeks, the germinated seeds were counted and seedling growth was measured.

Germination percentage $=$ Number of germinating seeds $/$ Total number of seeds $\times 100$

\section{Sampling time}

During alfalfa florescence (June $15^{\text {th }}-$ June 25 th), ten plantings were selected at random to record observations on planting height, the branches of each plant, the average yield of single plant and the stem-leaf ratio (Shen et al., 2018). The alfalfa functional leaves were taken and mixed from each treatment to measure physiological indexes.

\section{Experimental method}

\section{Chlorophyll analysis}

The plants leaves washed with distilled water, then weighed it about $0.2 \mathrm{~g}$. Chlorophyll content in the leaves of treated and control plants were extracted in $80 \%$ acetone and $95 \%$ ethanol $20 \mathrm{ml}$, after $24 \mathrm{~h}$ dark extracted in $50{ }^{\circ} \mathrm{C}$ water bath, then determined the absorbance of the solution at 645 and $663 \mathrm{~nm}$. Chlorophyll content was expressed by following equations (Ahmadreza et al., 2009):

$$
\mathrm{Ca}=\left(12.71 \mathrm{~A}_{663}-2.59 \mathrm{~A}_{645}\right) \times(\mathrm{V} / \mathrm{M}) \times 1000
$$




$$
\begin{aligned}
& \mathrm{Cb}=\left(22.88 \mathrm{~A}_{645}-4.67 \mathrm{~A}_{663}\right) \times(\mathrm{V} / \mathrm{M}) \times 1000 \\
& \mathrm{Ct}=\left(8.04 \mathrm{~A}_{663}+20.29 \mathrm{~A}_{645}\right) \times(\mathrm{V} / \mathrm{M}) \times 1000
\end{aligned}
$$

$\mathrm{Ca}, \mathrm{Cb}, \mathrm{Ct}$ were chlorophyll-a, chlorophyll-b, and total chlorophyll, $\mathrm{V}$ were solvent amount, $M$ were leaf weight, $A_{645}, A_{663}$ were the absorbance value at $645 \mathrm{~nm}$ and $663 \mathrm{~nm}$.

\section{Enzyme activities analysis}

The SOD was determined with the nitroblue tetrazolium (NBT) method (Dai et al., 2011), while the POD determined with the guaiacol method (Shen et al., 2018); and the CAT determined with the ultraviolet absorption method. The content of malondialdehyde (MDA) was measured with the glucosinolate and pentobarbital acid colorimetric method (Nahla et al., 2015). The instrument used in the test was a 721 UVvisible spectrophotometer (model: U-T6, Made in China).

\section{Microstructure}

The functional leaves of the M0 generation plants were selected and cut along the middle veins in an inverted trapezoidal shape having a size of $5 \times 5 \mathrm{~mm}$. The samples were fixed with FAA (formalin-acetic acid-alcohol) solution and underwent conventional paraffin sections with a thickness of $5 \mu \mathrm{m}$ and then stained with Safranin'O/Fast Green. The slides were observed under a Nikon-DIAPHOT (Model: Diaphot TMD, Made in Japan) microscope. The mean of the 4 values of leaf thickness, vein thickness, palisade thickness and spongy thickness of the tested alfalfa was determined by Motic Image 2000 1.3. Cell tense ratio, Spongy ratio, Vein protuberant degree were calculated as follows:

Cell tense ratio $(\mathrm{CTR} \%)=$ Palisade tissue thickness $/$ Leaf thickness $\times 100($ Eq.4)

Spongy ratio $($ SR \%) $=$ Spongy tissue thickness / Leaf thickness $\times 100 \quad$ (Eq.5)

Vein protuberant degree $($ VPD $)=$ Vein thickness / Leaf thickness $\times 100$ (Eq.6)

\section{Statistical analysis}

The data were analyzed by using the Statistical Analysis System (SAS Inc. CARY, NC) and EXCEL software were used for the statistical analysis of data.

\section{Results}

\section{Alfalfa seed germination after mutagenesis}

The alfalfa seed germination rate is shown in Figure $1 a, b$. The results showed that the germination ability of the treated seeds was significantly increased by ${ }^{60} \mathrm{Co}-\gamma$ radiation from $50 \mathrm{~Gy}(85 \%)$ to $150 \mathrm{~Gy}(91.08 \%)$ as compared to the control $(82.33 \%)$, and then the seed germination percentage decreased gradually from $73.67 \%$ (300 Gy) to $50.43 \%$ (600 Gy). However, for the chemical mutagen treatment, the significant reduction in seed germination percentage $(72.67 \%)$ began at $0.1 \%$ of EMS and continued to decline to up to $44.57 \%$ at $0.4 \%$ (Fig. 1 b). The results suggested that ${ }^{60} \mathrm{Co}-$ 
$\gamma$ radiation could stimulate the alfalfa seed germination percentage at lower dose (50$50 \mathrm{~Gy}$ ), but higher doses (300-600Gy), inhibit the germination rate. However, EMS mutagenesis could always inhibit seed germination. It can be seen that the inhibition rate of seed germination by EMS treatment was significantly $(P<0.05)$ higher than low-dose (50-150 Gy) ${ }^{60} \mathrm{Co}-\gamma$ radiation treatment (Fig. 1).
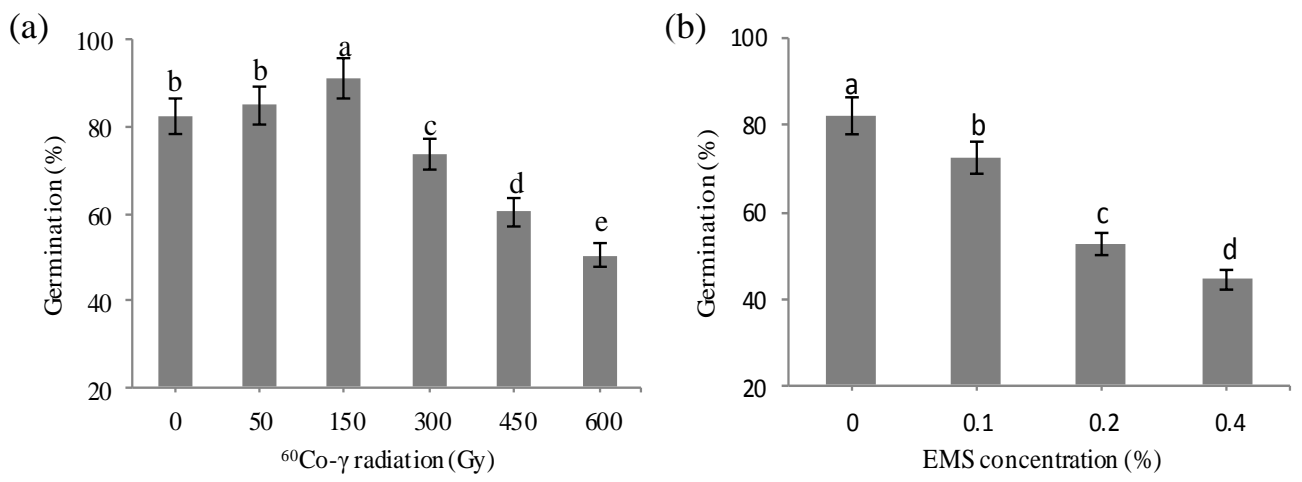

Figure 1. Effects of different mutagenic treatments on germination rate of alfalfa seeds $(a, b)$. Different small letters are significantly different $(p<0.05)$ in statistics. Each column represents the average of triplicate treatments, error bars represent the standard deviations of three replicates. (a) ${ }^{60} \mathrm{Co}-\gamma$ irradiation treatment and $(b)$ ethyl methyl sulfonate treatment (EMS)

\section{Alfalfa seedling growth after mutagenesis}

The measured root length of alfalfa is shown in Table 1. The root growth increased significantly from $50 \mathrm{~Gy}$ to $150 \mathrm{~Gy}$ of ${ }^{60} \mathrm{Co}-\gamma$ irradiation. The maximum root length was $4.50 \mathrm{~cm}$ at $150 \mathrm{~Gy}$, after that the root length decreased gradually with increase in doses of the mutagen. The minimum root length was $1.88 \mathrm{~cm}$ at $600 \mathrm{~Gy}$, which was significantly lower than their corresponding controls $(P<0.05)$. EMS mutagenesis inhibited root growth. The root length was significantly inhibited with increasing concentration $(P<0.05)$. Maximum root length was observed in $0.1 \%$ concentration $(2.56 \mathrm{~cm})$, and minimum root length was $1.38 \mathrm{~cm}$ in $0.4 \%$ concentration.

Table 1. Effect of different mutagenic treatment on root length of alfalfa

\begin{tabular}{c|c|c|c}
\hline Treatments & Dose & Root length $(\mathbf{c m})$ & Shoot length $(\mathbf{c m})$ \\
\hline CK & $0 \mathrm{~Gy}$ & $3.78 \pm 0.3 \mathrm{bc}$ & $3.19 \pm 0.41 \mathrm{~b}$ \\
\hline \multirow{3}{*}{${ }^{60} \mathrm{Co}-\gamma$} & $50 \mathrm{~Gy}$ & $3.86 \pm 0.47 \mathrm{bc}$ & $3.29 \pm 0.29 \mathrm{ab}$ \\
& $150 \mathrm{~Gy}$ & $4.50 \pm 0.38 \mathrm{a}$ & $3.79 \pm 0.11 \mathrm{a}$ \\
& $300 \mathrm{~Gy}$ & $3.21 \pm 0.48 \mathrm{c}$ & $3.00 \pm 0.45 \mathrm{~b}$ \\
& $450 \mathrm{~Gy}$ & $2.38 \pm 0.46 \mathrm{~d}$ & $2.52 \pm 0.42 \mathrm{c}$ \\
& $600 \mathrm{~Gy}$ & $1.88 \pm 0.24 \mathrm{e}$ & $2.06 \pm 0.34 \mathrm{~d}$ \\
\hline \multirow{2}{*}{ EMS } & $0.10 \%$ & $2.56 \pm 0.26 \mathrm{~d}$ & $2.82 \pm 0.36 \mathrm{bc}$ \\
& $0.20 \%$ & $2.01 \pm 0.44 \mathrm{~d}$ & $2.51 \pm 0.22 \mathrm{c}$ \\
& $0.40 \%$ & $1.38 \pm 0.63 \mathrm{e}$ & $2.06 \pm 0.15 \mathrm{~d}$ \\
\hline
\end{tabular}

Data in the table is the mean \pm SE. Average is the value of different agronomic traits in the different treatments. Different small letters in same column are statistically different at $p<0.05$ and same small letters in same column are not statistically different at $\mathrm{p}<0.05 .{ }^{60} \mathrm{CO}-\gamma:{ }^{60} \mathrm{Co}-\gamma$ irradiation treatment and EMS: ethyl methyl sulfonate treatment 
The variation trend of shoot length was consistent with that of root length. Maximum shoot length was observed in $150 \mathrm{~Gy}$ dose $(3.79 \mathrm{~cm})$ of ${ }^{60} \mathrm{Co}-\gamma$ radiation and $0.1 \%$ EMS concentration $(2.82 \mathrm{~cm})$ while the higher doses/concentrations retarded shoot length. In addition, it was found that the growth inhibition effect of EMS mutagenesis on seedlings was significantly $(P<0.05)$ greater than that of low-dose $(50-300 \mathrm{~Gy}){ }^{60} \mathrm{Co}-\gamma$ radiation. The increase in mutagenic doses/concentration lead to decrease in seedling vigor because of increase in physiological damage induced in the seeds and seedlings and variations in stimulation due to cell division rates as well as an activation of growth hormones such as auxin.

\section{Alfalfa agronomic traits after mutagenesis}

Variable degree of agronomic traits response was observed in different dose/concentrations (Table 2). The variation range of agronomic characters increased with the increase of mutagenic dose/concentrations. The fresh grass yield increased from 5.24 to $13.85 \%$ when the ${ }^{60} \mathrm{Co}-\gamma$ treatment dose increased from $50 \mathrm{~Gy}$ to $150 \mathrm{~Gy}$, and then it decreased with increasing dose. The fresh grass yield reduction ranged from $4.51 \%$ in 300 Gy to $21.23 \%$ in 600 Gy dose compare to control. While for EMS treatment, its reduction ranged from $3.24 \%$ in $0.1 \%$ EMS to $32.69 \%$ in $0.4 \%$ EMS. The change trend of plant height was consistent with that of fresh grass yield. The highest plant height was $139.70 \mathrm{~cm}$ in $150 \mathrm{~Gy}$, and the lowest plant height was $59.30 \mathrm{~cm}$ in $0.4 \%$ EMS. In summary, compared with the control, the effects of ${ }^{60} \mathrm{Co}-\gamma$ radiation treatment on grass yield and plant height increased first and then decreased, while EMS treatment showed a significant inhibitory effect $(P<0.05)$.

Table 2. Effect of mutagenic treatments on agronomic traits

\begin{tabular}{c|c|c|c|c|c|c|c|c|c}
\hline \multirow{2}{*}{ Treatments } & \multirow{2}{*}{ Dose } & \multicolumn{2}{|c|}{ Yield/plant (g) } & \multicolumn{2}{c|}{ Height (cm) } & \multicolumn{2}{c}{ Branch/per plant } & \multicolumn{2}{c}{ Stem-leaf ratio (\%) } \\
\cline { 3 - 10 } & & Amplitude & Mean & Amplitude & Mean & Amplitude & Mean & Amplitude & Mean \\
\hline $\mathrm{CK}$ & 0 & $168.65-198.52$ & $185.63 \mathrm{~b}$ & $114.12-125.25$ & $124.30 \mathrm{~b}$ & $17-20$ & $14.19 \mathrm{c}$ & $2.08-2.70$ & $2.67 \mathrm{a}$ \\
\hline \multirow{3}{*}{${ }^{60} \mathrm{Co}-\gamma$} & $50 \mathrm{~Gy}$ & $54.21-219.22$ & $195.36 \mathrm{~b}$ & $126.55-141.62$ & $133.70 \mathrm{a}$ & $16-25$ & $15.22 \mathrm{bc}$ & $1.44-2.05$ & $2.79 \mathrm{a}$ \\
& $150 \mathrm{~Gy}$ & $77.87-264.44$ & $211.34 \mathrm{a}$ & $110.25-152.55$ & $139.70 \mathrm{a}$ & $18-28$ & $17.17 \mathrm{~b}$ & $2.59-3.23$ & $2.13 \mathrm{~b}$ \\
& $300 \mathrm{~Gy}$ & $69.14-197.25$ & $177.25 \mathrm{c}$ & $102.46-141.04$ & $117.7 \mathrm{c}$ & $15-28$ & $17.80 \mathrm{~b}$ & $1.38-2.13$ & $1.97 \mathrm{~b}$ \\
& $450 \mathrm{~Gy}$ & $46.14-297.34$ & $164.23 \mathrm{~d}$ & $82.25-103.56$ & $98.30 \mathrm{~d}$ & $14-25$ & $19.56 \mathrm{ab}$ & $1.45-2.26$ & $1.55 \mathrm{c}$ \\
& $600 \mathrm{~Gy}$ & $54.54-284.27$ & $146.22 \mathrm{e}$ & $86.51-105.65$ & $94.70 \mathrm{~d}$ & $19-25$ & $20.40 \mathrm{a}$ & $1.28-2.49$ & $1.47 \mathrm{c}$ \\
\hline \multirow{3}{*}{$\mathrm{EMS}$} & $0.10 \%$ & $79.14-198.57$ & $179.62 \mathrm{bc}$ & $92.45-132.22$ & $104.13 \mathrm{~cd}$ & $15-22$ & $17.73 \mathrm{~b}$ & $2.01-2.58$ & $2.03 \mathrm{ab}$ \\
& $0.20 \%$ & $61.38-176.43$ & $147.96 \mathrm{e}$ & $56.34-90.21$ & $86.70 \mathrm{e}$ & $15-28$ & $19.85 \mathrm{ab}$ & $1.95-2.47$ & $2.32 \mathrm{a}$ \\
& $0.40 \%$ & $44.51-160.37$ & $124.95 \mathrm{f}$ & $44.29-75.36$ & $59.30 \mathrm{f}$ & $17-27$ & $21.94 \mathrm{a}$ & $1.21-2.07$ & $1.83 \mathrm{~b}$ \\
\hline
\end{tabular}

Data in the table is the mean \pm SE. Average is the value of different physiological indexes in the different treatments. Different small letters in same column are statistically different at $\mathrm{p}<0.05$ and same small letters in same rows are not statistically different at $\mathrm{p}<0.05$. CK: control treatment ${ }^{60} \mathrm{Co}-\gamma:{ }^{60} \mathrm{Co}-\gamma$ irradiation treatment and EMS: ethyl methyl sulfonate treatment

Both mutagenesis treatments promoted alfalfa branching. The branch number of alfalfa enhanced with the increase in dose/concentration both in physical and chemical mutagens. It reaches the maximum value at $600 \mathrm{~Gy}$, nearly $43.76 \%$ more than the control. Similarly, the branch number was improved from $24.95 \%$ in $0.1 \%$ EMS to $54.61 \%$ in $0.4 \%$ EMS. Overall, EMS treatments are more conducive to increasing the number of alfalfa branches, but it is not significantly different from ${ }^{60} \mathrm{Co}-\gamma$ radiation treatment. The stem-leaf ratio was also different with the different mutagenesis. The difference of stem-leaf ratio were not significantly affected between low dose (50 Gy- 
$150 \mathrm{~Gy})$ and low concentration $(0.1 \%-0.2 \%)$, but there were significant reduction $(P<0.05)$ with the increase of dose and concentration. The decrease of the stem-leaf ratio indicates that alfalfa leaf increased and the nutrient content of alfalfa was improved.

\section{Influence of mutagen on the chlorophyll content}

The chlorophyll content and the ratio of chlorophyll $\mathrm{a} / \mathrm{b}$ can reflect the adaptability of plant varieties, and also an important indicator for the utilization of environmental factors. The chlorophyll content obtained according to Equations 1-3 is shown in Table 3. The chlorophyll a content of alfalfa leaves under the treatments with 150 Gy ${ }^{60} \mathrm{Co}-\gamma$ radiation and $0.4 \%$ EMS treatment were significantly higher than their corresponding controls $(p<0.05)$. The changes trend of chlorophyll $\mathrm{b}$ content was consistent with chlorophyll a content under different mutagenesis treatments. The change of total chlorophyll of alfalfa was increasing at first and then decreasing under the ${ }^{60} \mathrm{Co}-\gamma$ radiation, and it increased with the increase of EMS treatment concentration. Under low dose $(50-150 \mathrm{~Gy}){ }^{60} \mathrm{Co}-\gamma$ radiation treatment and $0.4 \%$ EMS treatment, the total chlorophyll content was significantly $(p<0.05)$ higher than other treatments. The maximum was observed in $150 \mathrm{~Gy}\left(4.36 \mathrm{mg}^{\bullet} \mathrm{g}^{-1}\right)$ and $0.4 \%$ EMS concentration $\left(4.27 \mathrm{mg} \bullet \mathrm{g}^{-1}\right)$. Except for $0.4 \%$ EMS treatment, the proportion of chlorophyll $\mathrm{a} / \mathrm{b}$ in alfalfa leaves was basically lower than the control.

Table 3. Effect of mutagenic treatments on chlorophyll content

\begin{tabular}{c|c|c|c|c|c}
\hline \multirow{2}{*}{ Treatments } & \multirow{2}{*}{ Dose } & \multicolumn{4}{c}{ Chl. content (mg•g-1) } \\
\cline { 3 - 6 } & & Chl.a & Chl.b & Total Chl. & Chl. a/b \\
\hline CK & 0 & $2.94 \pm 0.10 \mathrm{~b}$ & $0.94 \pm 0.03 \mathrm{a}$ & $3.88 \pm 0.09 \mathrm{~b}$ & $3.13 \pm 0.08 \mathrm{a}$ \\
\hline \multirow{3}{*}{${ }^{60} \mathrm{Co}-\gamma$} & $50 \mathrm{~Gy}$ & $3.06 \pm 0.19 \mathrm{ab}$ & $1.07 \pm 0.08 \mathrm{a}$ & $4.13 \pm 0.19 \mathrm{a}$ & $2.86 \pm 0.11 \mathrm{~b}$ \\
& $150 \mathrm{~Gy}$ & $3.21 \pm 0.51 \mathrm{a}$ & $1.15 \pm 0.43 \mathrm{a}$ & $4.36 \pm 0.15 \mathrm{a}$ & $2.79 \pm 0.31 \mathrm{~b}$ \\
& $300 \mathrm{~Gy}$ & $2.90 \pm 0.23 \mathrm{~b}$ & $0.95 \pm 0.07 \mathrm{a}$ & $3.85 \pm 0.17 \mathrm{~b}$ & $3.05 \pm 0.12 \mathrm{a}$ \\
& $450 \mathrm{~Gy}$ & $2.93 \pm 0.01 \mathrm{~b}$ & $0.95 \pm 0.12 \mathrm{a}$ & $3.89 \pm 0.31 \mathrm{~b}$ & $3.07 \pm 0.22 \mathrm{a}$ \\
& $600 \mathrm{~Gy}$ & $2.81 \pm 0.14 \mathrm{~b}$ & $0.91 \pm 0.27 \mathrm{a}$ & $3.72 \pm 0.51 \mathrm{~b}$ & $3.09 \pm 0.07 \mathrm{a}$ \\
\hline \multirow{2}{*}{ EMS } & $0.10 \%$ & $2.87 \pm 0.28 \mathrm{~b}$ & $0.92 \pm 0.03 \mathrm{a}$ & $3.79 \pm 0.06 \mathrm{~b}$ & $3.12 \pm 0.07 \mathrm{a}$ \\
& $0.20 \%$ & $2.89 \pm 0.11 \mathrm{~b}$ & $0.93 \pm 0.14 \mathrm{a}$ & $3.82 \pm 0.38 \mathrm{~b}$ & $3.11 \pm 0.24 \mathrm{a}$ \\
& $0.40 \%$ & $3.26 \pm 0.03 \mathrm{a}$ & $1.01 \pm 0.14 \mathrm{a}$ & $4.27 \pm 0.33 \mathrm{a}$ & $3.23 \pm 0.23 \mathrm{a}$ \\
\hline
\end{tabular}

Data in the table is the mean \pm SE. Average is the value of different physiological indexes in the different treatments. Different small letters in same column are statistically different at $p<0.05$ and same small letters in same rows are not statistically different at $\mathrm{p}<0.05$. CK: control treatment ${ }^{60} \mathrm{Co}-\gamma$ : ${ }^{60} \mathrm{Co}-\gamma$ irradiation treatment and EMS: ethyl methyl sulfonate treatment. Chl. content: chlorophyll content, Chl. a: chlorophyll a content, Chl. b: chlorophyll b content, Total Chl.: total chlorophyll content, Chl. a/b: the ratio of chlorophyll a to chlorophyll b

\section{Influence of mutagen on the enzyme activity}

The activity of SOD, POD, CAT and MDA content of alfalfa after treatments are shown in Table 4. The ${ }^{60} \mathrm{Co}-\gamma$ radiation treatment promoted the accumulation of SOD in alfalfa. The SOD activity was significantly increased $(P<0.05)$ in low dose, and after that it was decreased with the increase of dosage. However, the SOD activity increased with increasing of EMS treatment concentration, but was lower than that of control. The 
changes of POD activity and CAT activity were consistent in the two mutagenesis treatments and higher than their corresponding controls $(p<0.05)$. The POD and CAT activity increased when treated by 50-150 Gy, and decreased when treated by 300$600 \mathrm{~Gy}$. The activity of the two enzymes decreased with the increase of EMS concentration. Furthermore, from the change of enzyme activity analysis it was shown that the promoted strength of activity was as follows: POD $>$ CAT $>$ SOD. The activity of three antioxidant enzymes in low-dose $(50-150 \mathrm{~Gy}){ }^{60} \mathrm{Co}-\gamma$ radiation treatment were higher than in low-dose (0.1-0.2\%) EMS treatment, and the enzyme activity at 150 Gy dose was significantly higher than all other treatments $(p<0.05)$. The activity of the three enzymes showed the tendency of increasing firstly and then decreasing, this is possibly because of that the higher dose of mutagen shifted from stimulation to inhibition or disturbances for the enzyme activity.

Compared with the control, the MDA content increased first and then decreased under the two mutagenesis treatments. In all the treatments, the MDA content under $0.1 \%$ EMS treatment was significantly higher than other treatments $(p<0.05)$.

Table 4. Effect of different doses mutagenic treatments on physiological indexes

\begin{tabular}{|c|c|c|c|c|c|}
\hline Treatments & Dose & $\begin{array}{c}\text { SOD } \\
\left(\mathbf{U}^{-1} g^{-1}\right)\end{array}$ & $\begin{array}{c}\text { POD } \\
\left(\mathrm{U} \cdot \mathrm{gFW} \cdot \mathrm{min}^{-1}\right)\end{array}$ & $\begin{array}{c}\text { CAT } \\
\left(\mathrm{U} \bullet \mathrm{gFW} \bullet \mathrm{min}^{-1}\right)\end{array}$ & $\begin{array}{c}\text { MDA } \\
\left(\mu \mathrm{mol} \cdot \mathrm{g}^{-1}\right)\end{array}$ \\
\hline $\mathrm{CK}$ & $0 \mathrm{~Gy}$ & $230.29 \pm 33.85 \mathrm{~b}$ & $2443.78 \pm 305.23 \mathrm{~d}$ & $250.00 \pm 75.85 \mathrm{f}$ & $35.64 \pm 3.20 \mathrm{c}$ \\
\hline \multirow{5}{*}{${ }^{60} \mathrm{CO}-\gamma$} & $50 \mathrm{~Gy}$ & $242.63 \pm 22.47 b$ & $4218.44 \pm 746.86 b$ & $474.40 \pm 139.46 b$ & $37.89 \pm 1.52 b$ \\
\hline & $150 \mathrm{~Gy}$ & $271.37 \pm 9.12 \mathrm{a}$ & $6753.78 \pm 421.58 \mathrm{a}$ & $541.86 \pm 43.35 \mathrm{a}$ & $37.77 \pm 8.33 b$ \\
\hline & $300 \mathrm{~Gy}$ & $233.42 \pm 7.81 \mathrm{~b}$ & $4087.56 \pm 708.19 c$ & $404.00 \pm 92.8 \mathrm{c}$ & $36.51 \pm 13.83 c$ \\
\hline & $450 \mathrm{~Gy}$ & $219.70 \pm 16.53 c$ & $3930.22 \pm 2353.59 c$ & $417.49 \pm 89.24 c$ & $35.84 \pm 24.88 \mathrm{c}$ \\
\hline & $600 \mathrm{~Gy}$ & $155.10 \pm 2.04 \mathrm{~d}$ & $3904.67 \pm 298.09 \mathrm{c}$ & $300.93 \pm 38.95 \mathrm{e}$ & $35.26 \pm 4.92 \mathrm{~cd}$ \\
\hline \multirow{3}{*}{ EMS } & $0.10 \%$ & $209.52 \pm 19.46 \mathrm{c}$ & $4004.67 \pm 28.09 \mathrm{c}$ & $436.27 \pm 24.37 b c$ & $39.77 \pm 8.33 \mathrm{a}$ \\
\hline & $0.20 \%$ & $214.70 \pm 16.53 c$ & $4130.22 \pm 23.59 b c$ & $331.20 \pm 39.83 \mathrm{de}$ & $34.57 \pm 12.52 \mathrm{~d}$ \\
\hline & $0.40 \%$ & $221.46 \pm 14.50 \mathrm{bc}$ & $6416.32 \pm 19.33 a$ & $441.73 \pm 43.03 b c$ & $36.95 \pm 0.46 b c$ \\
\hline
\end{tabular}

Data in the table is the mean $\pm \mathrm{SE}$. Average is the value of different physiological indexes in the different treatments. Different small letters in same column are statistically different at $\mathrm{p}<0.05$ and same small letters in same rows are not statistically different at $\mathrm{p}<0.05$. CK: control treatment, ${ }^{60} \mathrm{Co}-\gamma$ : ${ }^{60} \mathrm{Co}-\gamma$ irradiation treatment, EMS: ethyl methyl sulfonate treatment. SOD: the abbreviation of superoxide dismutase, POD: the abbreviation of peroxidase, CAT: the abbreviation of hydrogen peroxidase, MDA: the abbreviation of malondialdehyde

\section{Microstructure of leaves}

In the experiment, different mutagenic treatments showed different effects on the microstructure of the alfalfa leaves from the M0 generation. The mutagenic direction and degrees varied with the mutagenic methods and doses (Loutou et al., 2016; Zhu et al., 2015). In this study (Table 5), the leaf thickness of Longmu806 alfalfa was significantly higher than its corresponding controls $(p<0.05)$. The leaf thickness under $0.1 \%$ EMS treatment was significantly $(p<0.05)$ higher than the control and ${ }^{60} \mathrm{Co}-\gamma$ radiation treatment. The vein protuberant degree (VPD) was calculated according to Equation 6, and the VPD of all the treatments were significantly less than their corresponding controls $(p<0.05)$ (Table 5; Fig. 2).

The leaf thickness of plants primarily depends upon the thickness of the palisade tissue and the spongy tissue. In this experiment, the thicknesses of the palisade tissues 
and the spongy tissues for all the treatments were higher than their corresponding controls. This proves that a thicker palisade tissue and spongy tissue could be the result of mutation treatment. In this study, the changes occurred in the compactness and looseness of cell structure of the alfalfa was different. The cell tense ratio (CTR) was calculated according to Equation 4, and the compactness of cell structure for the lower dose/concentration treatments was lower than control, but it was significantly $(p<0.05)$ higher than control under $600 \mathrm{~Gy}{ }^{60} \mathrm{Co}-\gamma$ and $0.4 \%$ EMS treatment. However, the spongy ratio (SR) was calculated according to Equation5, the looseness of cell structure increased compared to control in all treatments.

Table 5. Comparison of main structural features (mean \pm SE) of alfalfa under different mutagenic treatments $(\mu \mathrm{m})$

\begin{tabular}{c|c|c|c|c|c|c|c|c}
\hline \multicolumn{2}{c|}{ Treatments } & $\begin{array}{c}\text { Leaf } \\
\text { thickness }\end{array}$ & $\begin{array}{c}\text { Vein } \\
\text { thickness }\end{array}$ & $\begin{array}{c}\text { Palisade } \\
\text { thickness }\end{array}$ & $\begin{array}{c}\text { Spongy } \\
\text { thickness }\end{array}$ & VPD (\%) & CTR (\%) & SR (\%) \\
\hline \multicolumn{2}{c|}{$\mathrm{CK}$} & $298.93 \pm 7.61 \mathrm{~d}$ & $877.34 \pm 6.57 \mathrm{a}$ & $129.00 \pm 3.25 \mathrm{~d}$ & $95.98 \pm 1.99 \mathrm{e}$ & $294.34 \pm 5.54 \mathrm{a}$ & $43.48 \pm 0.63 \mathrm{c}$ & $31.37 \pm 0.27 \mathrm{c}$ \\
\hline${ }^{60} \mathrm{CO}-\gamma$ & 50 & $347.70 \pm 6.45 \mathrm{c}$ & $776.94 \pm 8.61 \mathrm{c}$ & $145.43 \pm 2.25 \mathrm{c}$ & $119.52 \pm 3.72 \mathrm{~cd}$ & $223.41 \pm 2.84 \mathrm{~b}$ & $41.86 \pm 0.35 \mathrm{c}$ & $34.84 \pm 0.26 \mathrm{~b}$ \\
$(\mathrm{~Gy})$ & 150 & $376.70 \pm 6.49 \mathrm{~b}$ & $786.94 \pm 8.01 \mathrm{c}$ & $149.32 \pm 2.78 \mathrm{bc}$ & $124.06 \pm 3.46 \mathrm{c}$ & $209.67 \pm 2.44 \mathrm{~d}$ & $39.52 \pm 0.38 \mathrm{c}$ & $32.51 \pm 0.64 \mathrm{bc}$ \\
& 600 & $332.19 \pm 7.60 \mathrm{c}$ & $690.55 \pm 2.76 \mathrm{~d}$ & $167.57 \pm 2.34 \mathrm{~b}$ & $181.34 \pm 3.53 \mathrm{a}$ & $207.19 \pm 3.35 \mathrm{~d}$ & $50.71 \pm 0.45 \mathrm{~b}$ & $39.37 \pm 0.48 \mathrm{a}$ \\
\hline EMS & 0.1 & $432.42 \pm 8.65 \mathrm{a}$ & $832.61 \pm 0.58 \mathrm{~b}$ & $170.95 \pm 3.98 \mathrm{~b}$ & $152.19 \pm 3.74 \mathrm{~b}$ & $192.25 \pm 9.63 \mathrm{~d}$ & $39.89 \pm 0.54 \mathrm{c}$ & $35.52 \pm 0.35 \mathrm{~b}$ \\
$(\%)$ & 0.4 & $306.11 \pm 9.31 \mathrm{~d}$ & $659.65 \pm 4.53 \mathrm{e}$ & $186.65 \pm 1.01 \mathrm{a}$ & $117.73 \pm 0.81 \mathrm{~d}$ & $215.03 \pm 2.74 \mathrm{~cd}$ & $60.14 \pm 0.25 \mathrm{a}$ & $38.15 \pm 0.61 \mathrm{ab}$ \\
\hline
\end{tabular}

Data in the table is the mean \pm SE. Average is the value of different physiological indexes in the different treatments. Different small letters in same column are statistically different at $p<0.05$ and same small letters in same rows are not statistically different at $\mathrm{p}<0.05$. CK: control treatment, ${ }^{60} \mathrm{Co}-\gamma$ : ${ }^{60} \mathrm{Co}-\gamma$ irradiation treatment, EMS: ethyl methyl sulfonate treatment. VPD: vein protuberant degree, CTR: cell tense ratio, SR: spongy ratio

\section{Discussion}

Mutation induction through the use of different kinds of mutagens has proved vital in inducing variability that could be exploited in the improvements of alfalfa growth and types. It is therefore the origin of genetic variability as suggested by Tamarin (1999). The changed mean germination percent due to various EMS concentrations and ${ }^{60} \mathrm{Co}-\gamma$ radiation doses revealed the effects of the mutagen in the germination process. In this study, the germination of seeds decreased with increase in dose/concentration both in physical and chemical mutagens except 50-150 Gy. This result is consistent with the findings of Dhakshanamoorthy et al. (2010) who reported the germination of Barbados nut decreased with the increase dose of irradiation mutagen. This reduction/stimulation in seed germination might have been due to the effect of mutagens on meristematic tissues of the seed, or may be either due to the inhibition or promotion in physiological and biological process necessary for seed germination (Wu et al., 2013).

The reduction in lengths of root and shoot due to mutagenic treatments has been observed in alfalfa (Shen et al., 2018). In the present study, the root and shoot length decreased with increased doses of radiation except $50 \mathrm{~Gy}$, which is in agreement with the findings of Ge et al. (2011) who reported the seedling germination rate and seedling growth of Chrysanthemu morifolium Ramat. decreased obviously when treated with high dose of ${ }^{60} \mathrm{Co}-\gamma$ radiation. Li et al. (2013) demonstrated that the seedling emergence rate and seedling height of watermelon (Citrullus lanatus (Thunb.) Matsum. et Nakai) decreased significantly as the radiation dose increased. However, in this experiment, both root length and stem length of alfalfa seedlings were inhibited by EMS. Huo et al. 
(2014) using EMS treated the seeds of Vicia sativa L., the result showed that the seedling growth were inhibited, and the inhibition enhanced with longer processing time. The increase in mutagenic doses lead to decrease in seedling vigor because of increase in physiological damage induced in the seeds and seedlings (Anbarasan et al., 2013) and variations in stimulation due to cell division rates as well as an activation of growth hormones such as auxin (Zaka et al., 2004). The reduced seedling growth in mutagenically treated seeds might be due to injury caused at cellular level because of gene controlled biochemical processes or acute chromosomal aberrations or both (Satpute et al., 2012).
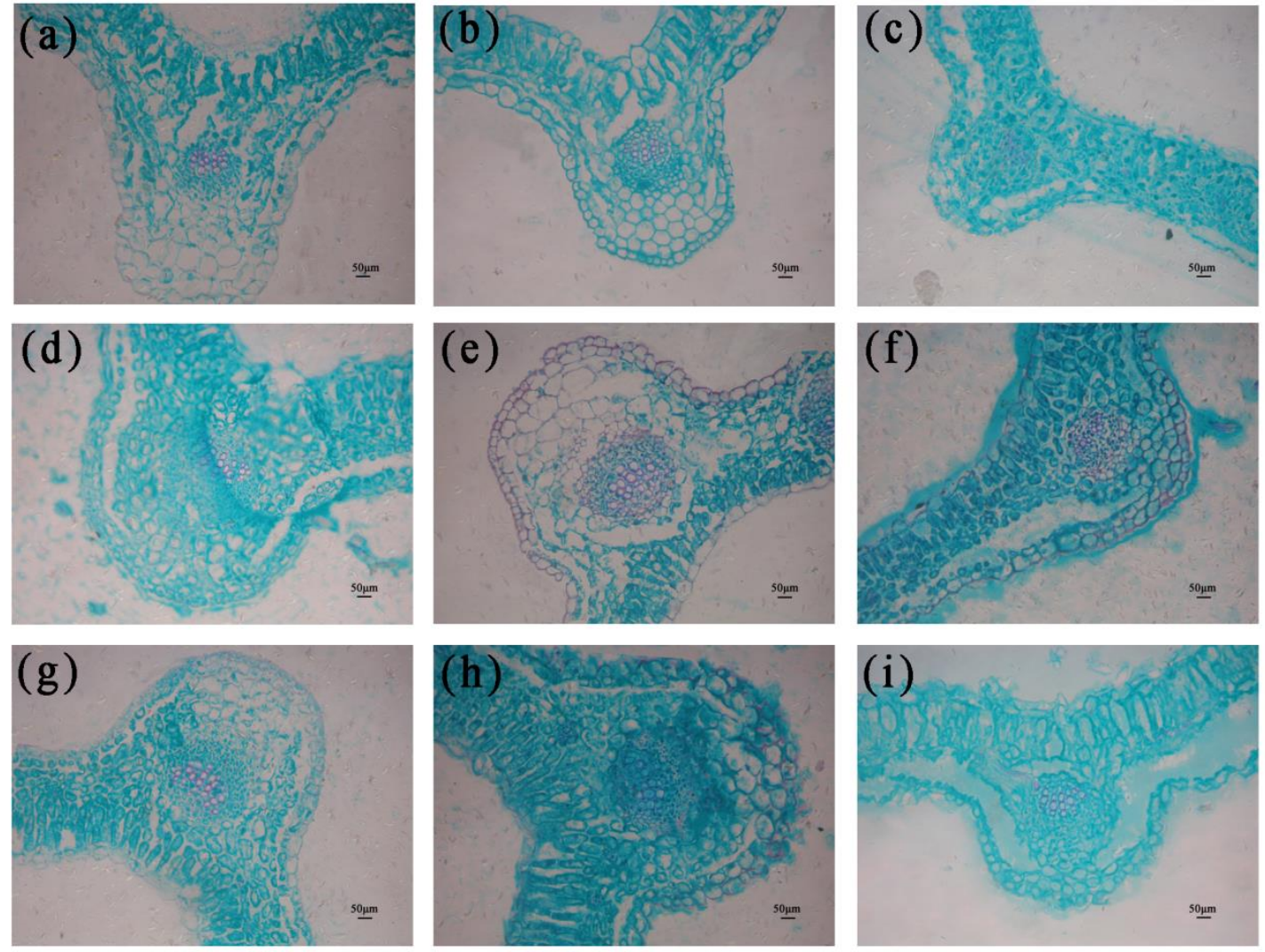

Figure 2. Microstructure changes of leaf veins. a: control treatment, $b: 0.1 \%$ ethyl methyl sulfonate treatment, $c: 0.2 \%$ ethyl methyl sulfonate treatment, $d: 0.4 \%$ ethyl methyl sulfonate treatment, $e: 50 \mathrm{~Gy}{ }^{60} \mathrm{Co}-\gamma$ irradiation treatment, $f: 150 \mathrm{~Gy}{ }^{60} \mathrm{Co}-\gamma$ irradiation treatment, $g$ : $300 \mathrm{~Gy}{ }^{60} \mathrm{Co}-\gamma$ irradiation treatment, $h: 450 \mathrm{~Gy}{ }^{60} \mathrm{Co}-\gamma$ irradiation treatment, $i$ : $600 \mathrm{~Gy}{ }^{60} \mathrm{Co}-\gamma$ irradiation treatment

In this study, the change of fresh yield had the same trend with the plant height, which was firstly ascending and then descending following the dose increasing (Table 2). This might be due to the alteration of its genome integrated by environmental signals as reported by Wang et al. (2010). For the reason of the number of branch increased after mutagenesis, it might be caused by increasing the rates of cellular division and expansion at their meristematic regions. This is also in agreement with the findings of Yang et al. (2012) who reported that the increase of branch number of alfalfa was due to radiation mutagenesis. But it was in contrast with the findings of 
Maluszynski et al. (2001) who independently reported that the decrease of branch number was due to induced mutation in rice and other cereals. For the reason of that the stem-leaf ratio increased in lower dose (50 Gy) (Table 2), the explanation might be due to a greater increase in the yield of fresh forage. Following the dose increasing and the different concentrations of EMS, the stem-leaf ratio decreased, this means that the leaf area or leaf number was increasing, as leaf is a major nutrition tank and hence it would be helpful to improve the quality of alfalfa. This result was consistent with the reports of Yang et al. (2015) who reported that mutagen could decrease the stem-leaf ratio, and improve leaf number and increase leaf area.

In the present study, $150 \mathrm{~Gy}$ dose of ${ }^{60} \mathrm{Co}-\gamma$ radiation and $0.4 \%$ EMS all increased the content of chlorophyll in alfalfa. This is also in agreement with the findings of Yang et al. (2017) who reported increased in chlorophyll content of tomato and pepper due to radiation mutagenesis. Since the content of chlorophyll has a direct impact on the strength of photosynthesis, this also shows that mutagenesis could promote the photosynthesis of crops.

The active oxygen radical in plant cells is in a state of dynamic equilibrium under normal conditions. When plants are stimulated by mutagen, plants are equipped with antioxidant systems composed of low-molecular weight antioxidants and enzymes that protect the cell from the damaging effects (Ma et al., 2011). In the present study, the SOD activity increased in the range of 50-300 Gy, and then decreased as the dose gradually increased (Table 4). The later occurred decrease might be related to that the irradiated alfalfa suffered excessive mutagen stress. Both POD and CAT were found significantly increased in the leaf of alfalfa under ${ }^{60} \mathrm{Co}-\gamma$ radiation and EMS treatments, their activities also showed the trend of decreasing as the doses/concentrations increasing. The change of the antioxidant enzyme activity indicated that plants suffered oxidative stress induced by the over-production of the ROS, which was consistent with the results of Uruc and Demirezen (2012). The MDA is one of the membrane fat peroxidation products, its content can reflect the cell membrane fat peroxidation degree and the cell suffering injury degree (Pan et al., 2002). Under mutagen stress, the accumulation of reactive oxygen free radicals beyond a certain limit in alfalfa body will cause the membrane fat peroxidation, and its product MDA will accumulate (Gao et al., 2003) massively. In this study, the content of MDA was increased compared to their corresponding controls under the different mutagens stress, but the difference was not significant $(p<0.05)$. It indicates that the antioxidant enzyme system has certain protective effect on alfalfa under mutagenesis.

The structural characteristics of cells, including the thicknesses of the palisade tissue and the spongy tissue and the compactness and the looseness of the leaf tissue structures all contribute to the resistance mechanism of plants. According to Pavel et al. (2016) more compact the cell structure, the stronger the cold resistance of the species. Feng et al. (2008) demonstrated that after completing a space flight, leaves of alfalfa sowed increased thickness with high relative water content. In the same experiment, the thickness and compactness of spongy tissue was also increased. Zhang et al. (2015) showed that with respect to the microstructure of the alfalfa leaves, the spongy tissue and the palisade tissue reacted differently to the space mutagenesis, which had a bigger effect on the spongy tissue than on the palisade tissue. In this study, after mutagenesis, the thickness of the leaves increased, and the protrusion degree of the veins decreased. The thicknesses of the palisade tissues and the spongy tissues for all the treatments were significantly higher than their corresponding controls $(p<0.05)$, which was consistent 
with the conclusion of Dhakshanamoorthy et al. (2010). Compared to the control, the cell compactness structure of cells and looseness did not change obviously in the low dose/concentration of all mutagenesis treatments, but which were increased with the increase of dose/concentration. There are beneficial in increasing the adversity resistance and cold resistance capacity of alfalfa.

\section{Conclusion}

Artificial mutation by using of ${ }^{60} \mathrm{Co}-\gamma$ radiation and EMS proves vital in the improvement of genetic variability in alfalfa. Both mutagenesis treatments can enhance the physiological activity of alfalfa. Furthermore, ${ }^{60} \mathrm{Co}-\gamma$-ray treatment can promote the growth of plant height and increase the yield. EMS treatment can inhibit the plant height and promote the branching of alfalfa. In this study the $150 \mathrm{~Gy}$ dose of ${ }^{60} \mathrm{Co}-\gamma$ radiation and $0.4 \%$ EMS are better mutagenic treatment for screening mutants. It shows that in the future research, the mutagenesis treatment method can be selected according to the actual production needs. This study analyzes the growth and physiological changes of alfalfa. In the future, it is necessary to further study the molecular mechanism of its mutation to provide a theoretical basis for the screening and breeding of new mutants.

Acknowledgments. This research was supported by the Heilongjiang province postdoctoral special funding (LBH-TZ06020). The authors are grateful to the Institute of Atomic Energy Utilization of Chinese Academy of Agricultural Sciences for providing technical support for this study.

\section{REFERENCES}

[1] Adamu, A. K., Chung, S. S., Abubakar, S. (2004): The effect of ionizing radiation (Gamma rays) on tomato (s.n.). - Nigerian Journal of Experimental Biology 5(2): 185193.

[2] Ahmadreza, M., Alireza, N., Abdolrassoul, S. M., Hossein, M., Homan, L., Mohsen, K. (2009): Vegetation mapping of the Mond Protected Area of Bushehr Province (SouthWest Iran). - Journal of Integrative Plant Biology 3: 217-223.

[3] Anbarasan, K., Sivalingam, D., Rajendran, R., Anbazhagan, M., Chidambaram, A. A. (2013): Studies on the mutagenic effect of EMS on seed germination and seedling characters of sesame (Sesamum indicum L.) Var.TMV3. - International Journal of Research in Biological Sciences 3(1): 68-70.

[4] Dai, H. P., Zhang, P. P., Lu, C., Jia, G. L., Song, H., Ren, X. M., Chen, J. (2011): Leaf senescence and reactive oxygen cultivars metabolism of broomcorn millet (Panicum miliaceum L.) under drought condition. - Aust. J. Crop Sci. 5: 1655-1660.

[5] Dhakshanamoorthy, D., Selvaraj, R., Chidambaram, A. (2010): Physical and chemical mutagenesis in Jatropha curcas L. to induce variability in seed germination, growth and yield traits. - Rom. J. Biol. Plant Biol. 55: 113-125.

[6] Dhawi, F., Al-Khayri, J. M. (2008): Magnetic fields induce changes in photosynthetic pigments content in date palm (Phoenix dactylifera L.) seedlings. - Open Agr. J. 2: 121125 .

[7] Dhawi, F., Al-Khayri, J. M. (2009): Magnetic field increase weight and water content in date palm (Phoenix dactylifera L.). - J. Agr. Sci. Tech. 2: 23-29.

[8] Feng, P. (2008): Effects of Alfalfa Seed Moisture Content on Mutagenic of Satellite Carrying. - Gansu Agricultural University, LanZhou. 
[9] Feng, P., Shen, X. H., Li, R. L., Zheng, H. Y. (2018): Effect of different mutagenesis on microstructure and ultrastructure of alfalfa. - Pak. J. Bot. 50(4): 1387-1393.

[10] Gao, S. M., Chen, P. J., Guo, H. H. (2003): Study on cold acclimation and freezingtolerance mechanism of Aucuba japonica cv. Variegata. - Acta BOT Boreal-Occidenta Sin 23(12): 2113-2119.

[11] Ge, W. Y., Chang, G. Z., Chen, L., Zhao, Y., Wang, T. T., Ge, H (2011): Effects of ${ }^{60} \mathrm{Co}$ $\gamma$-rays irradiation on seed growth of ground-cover chrysanthemum. - Journal of Nuclear Agricultural Sciences 25(1): 0067-0070.

[12] Huo, Y. X., Wang, N., Zhang, J. Y., Zhang, Y., Kong, L. F. (2014): Effects of three mutagens on seed germination of Vicia sativa. - Pratacultural Science 31(3): 438-445.

[13] Kumar, G., Yadav, R. S. (2010): EMS induced genomic disorders in sesame (Sesamum indicum L.). - Romanian Journal of Biology 55(2): 97-104.

[14] Kumari, V., Chaudhary, H. K., Prasad, R., Kumar, A., Singh, A., Jambhulkar, S. (2016): Effect of mutagenesis on germination, growth and fertility in sesame (Sesamum indicum L.). - Annual Research \& Review in Biology 10(6): 1-9.

[15] Jain, S. M. (2011): Radiation-Induced Mutations for Date Palm Improvement. - In: Jain S., Al-Khayri J., Johnson D. (eds.) Date Palm Biotechnology. Springer, Dordrecht, pp. 271-286.

[16] Li, Y. M., Yang, S. M., Ji, H. B., Fang, C. Y., Pan, C. Y., Chen, N. L. (2013): Effects of ${ }^{60} \mathrm{Co}-\gamma$ irradiation intensity on watermelon seed germination and seedling growth. - Acta Agriculturae Boreali-occidentalis Sinica 22(3): 115-120.

[17] Loutou, M., Hajjaji, M., Mansori, M., Favotto, C., Hakkou, R. (2016): Heated blends of phosphate waste: microstructure characterization, effects of processing factors and use as a phosphorus source for alfalfa growth. - Environm. Manag. 4: 337-345.

[18] Ma, X. M., Zhang, Z. A., Deng, B., Zhang, Y. W., Gao, H. W., Pang, Y. Y., Yang, S. C., Liu, M. (2011): Study on protective enzyme activities of alfalfa leaves from satellite carrying seeds with different moisture contents. - Pratacultural Science 28(5): 783-787.

[19] Maluszynski, M., Szarejko, I., Barriga, P., Balcerzyk, A. (2001): Heterosis in crop mutant crosses and production of high yielding lines, using doubled haploid systems. - Euphytica 120: 387-398.

[20] Nahla, H., Noha, E. E. (2015): gamma irradiation effect on growth, physiological and molecular aspects of mustard plant. - American Journal of Agricultural Science 2(4): 164-170.

[21] Nan, L. L., Shi, S. L., Chen, J. G., Zhu, X. Q., Guo, Q. (2011): Field evaluation of the response and resistance to low temperature of alfalfa root with different root types during over-wintering. - Chinese Journal of Eco-Agriculture 19(3): 619-625 (in Chinese).

[22] Pan, X. Y., Cao, Q. D., Wang, G. X. (2002): Evaluation of lipid peroxidation for use in selection of cold hardiness cultivars of almond. - Acta Ecologica Sinica 22(11): 19021911.

[23] Pavel, L., Paul, K., Alexander, Z., Markku, P., Sergey, G. (2016): Recrystallization-based formation of uniform fine-grained austenite structure before polymorphic transition in high-strength steels for Arctic applications. - Int. Mech. and Mater. Eng. 11(1): 55-59.

[24] Satpute, R. A., Fultambkar, R. V. (2012): Effect of mutagenesis on germination, survival and pollen sterility in M 1 generation of soybean [Glycine max (L.) Merrill]. International Journal of Recent Trends in Science and Technology 2(3): 30-32.

[25] Shen, X. H., Jiang, C., Li, R. L., Li, J. D., Zheng, H. Y., Feng, P. (2016): The study on the cold resistance and physiology change of root in meadow fescue - alfalfa mixture and monoculture in winter. - Pratacultural Science 33(2): 268-275 (in Chinese).

[26] Shen, X. H., Jiang, C., Li, R. L., Feng, P., Zheng, H. Y. (2018): Effect of Magnetic Field -free Space on Growth Characteristics of Alfalfa. - Journal of Nuclear Agricultural Sciences 32(4): 0633-0638 (in Chinese).

[27] Tamarin, R. H. (1999): Principles of Genetics. - WCB/McGraw Hill, New York. 
[28] Uruc, P. K., Demirezen, Y. D. (2012): Response of antioxidant defences to Zn stress in three duckweed species. - Ecotoxicol. Environ. Saf. 85: 52-58.

[29] Wang, M., Wei, J. M., Guo, H. Q. (2010): Selection of space flight mutation of alfalfa and its polymorphic analysis by RAPD. - Acta Agrestia Sinica 17(6): 841-844.

[30] Wu, Y., Mu, L. Q. (2013): Effect of soil Pb, Cd stress on the growth, physiological and accumulation characteristics of four ornamental trees. - Journal of Soil and Water Conservation 27(5): 234-240 (in Chinese).

[31] Wu, X. L., Sun, C., Yan, L. P., Liu, C. L., Li, L., Xiang, Y., Qu, X. (2015): Effect of EMS on alfalfa seed germination and growth of Zhongmu No.1. - Heilongjiang Agricultural Science 45(2): 1-3+106 (in Chinese).

[32] Yang, D. N., Luo, Y. F., Xie, J. Q., Zhang, Q., Yang, L. (2015): Effects of acidity and/or aluminum stress on seed germination and seedling growth of alfalfa. - Acta Prataculturae Sinica 24(8): 103-109.

[33] Yang, H. S., Chang, G. Z., Bao, W. S., Chai. X. Q., Zhou, X. H. (2012): Morphological variation of space mutation in alfalfas. - Acta Prataculturae Sinica 21(5): 222-2.

[34] Yang, J. C., Du, G. F., Peng, J. Z. (2017): Comparison of cold resistance and nutritional quality of six tropical and subtropical leguminous forages during overwintering period. Pratacultural Science 34(04): 794-801.

[35] Zaka, R., Chenal, C., Misset, M. T. (2004): Effect of low doses of short-term gamma radiation on growth and development through two generations of Pisum sativum. Science of the Total Environment 320: 121-129.

[36] Zhang, W. J., Deng, B., Zhang, Y. W., Chen, B. J., Wang, X. Y. (2010): Effect on the leaf microstructure of different alfalfa varieties from spaceflight. - Acta Agrestia Sinica 2: 233-236.

[37] Zhang, Y. W., Han, J. G., Ren, W. B., Sun, H. L. (2015): Breeding by spaceflight mutagenesis and its application in forage breeding. - Pratacultura Sinica 2(10): 59-63.

[38] Zhang, Y. X., Tang, F. L., Zhang, H. Q., Han, W. B., Li, D. M., Shen, Z. B., Liu, L. X. (2007): Breeding of new variety Nongjing No. 1 of Medicago sativa L. by magnetic field free space. - Journal of Nuclear Agricultural Sciences 1: 34-37 (in Chinese).

[39] Zhang, Z. W., Sun, X. C., Yang, Y. W., Tian, J., Yang, L. Y., Zhan, Y. H., Bai, X. F., Liu, F. (2017): Effects of EMS treatment on growth and development of Cowpea. Chinese Journal of Tropical Crops 38(2): 218-225 (in Chinese).

[40] Zhu, H. S., Zhang, K., Dong, K. H., Yang, W. D., Zhao, X. (2015): Effect of drought stress on microstructural characteristic changes of medicago sativa 'Pingguan'. - Acta Prataculturae Sinica 4: 771-779. 